\title{
Sarcomatoid carcinoma of pancreas with liver metastases - A case report with review of literature
}

\author{
Rakul Nambiar K ${ }^{1}$, Roshni S ${ }^{2}$, Attokaran L Lijeesh ${ }^{2}$ and Rari P Mony ${ }^{3}$ \\ ${ }^{1}$ DM Medical Oncology Trainee, Regional Cancer Centre, India \\ ${ }^{2}$ Division of Clinical Oncology, Regional Cancer Centre, India \\ ${ }^{3}$ Division of Pathology, Regional Cancer Centre, India
}

\begin{abstract}
Sarcomatoid carcinoma is a rare, high-grade epithelial malignancy composed exclusively or predominantly of spindle cells often having features suggestive of epithelial derivation without features indicative of a specific line of mesenchymal differentiation. Sarcomatous carcinomas occur in diverse locations throughout the body, including the upper respiratory tract, upper and lower digestive tracts, genitourinary tract, breast and thyroid glands, among others. Sarcomatoid carcinoma rarely presents in the pancreas. The current study presents the case of a 41-year-old male with a tumor mass in the uncinate of the pancreas and liver metastases. Histopathology and immunohistochemistry of the liver metastases were confirmatory of metastatic sarcomatoid carcinoma. To the best of our knowledge, only nine cases of pancreatic sarcomatoid carcinoma have been reported in literature.
\end{abstract}

\section{Introduction}

Sarcomatoid carcinoma is an aggressive form of carcinoma composed of malignant spindle cell elements, with or without a coexsisting epithelial cell component. Ultrastructual analyses of sarcomatoid carcinoma have shown a spectrum of differentiation ranging from epithelial to mesenchymal-type features. Sarcomatoid carcinoma occurs very rarely in the pancreas. We describe here a 41-year-old male patient with sarcomatoid carcinoma of the pancreas with liver metastases with the supporting immunohistochemical (IHC) and histological findings. The current study represents only the tenth case of sarcomatoid carcinoma of the exocrine pancreas as defined above that has described in literature [1-11].

\section{Case report}

A 41-year-old man presented with vague abdominal discomfort and a five-kg weight loss over one month. His Eastern Cooperative Oncology Group performance score was one. Physical examination revealed a large, firm, nontender mass in the left upper quadrant of abdomen. All blood investigations were within normal limits, including those for tumor markers (CEA, CA 19-9, AFP, and CA 125). Abdominal computed tomography with contrast enhancement showed an illdefined hypodense lesion of size $22 \times 21 \mathrm{~mm}$ in the uncinate process of pancreas with multiple small rounded lesions in various segments of liver (suggestive of hepatic metastases) (Figure 1). CT guided biopsy of the liver lesion showed spindle cells having abundant eosinophilic cytoplasm and pleomorphic nuclei admixed with inflammatory cells (Figure 2). IHC staining was strongly positive for cytokeratin (Figure 3). Histology and IHC results confirmed the diagnosis of sarcomatoid carcinoma.

\section{Discussion}

Sarcomatoid carcinoma is characterized by proliferation of malignant spindle cell that in some cases demonstrates epithelial derivation without any ultrastructural or immunohistochemical features suggestive of a specific line of mesenchymal differentiation, but in some other cases demonstrate mesenchymal-type differentiation. The microscopically nondescript spindle cells typically express keratin or other epithelial-related markers consistent with an epithelial pathogenesis. Carcinosarcoma is an epithelial malignancy associated with sarcomatoid carcinoma with an equally aggressive clinical course that by definition demonstrates biphasic epithelial and mesenchymal differentiation. Therefore, for practical diagnostic purposes, carcinosarcoma is used interchangeably with sarcomatoid carcinoma. In the present case report, carcinosarcomas with heterologous mesenchymal elements demonstrating light microscopic and/or immunohistochemical evidence of specific mesenchymal (lipogenic, smooth or skeletal muscle, peripheral nerve sheath, vascular or osteo-/cartilaginous) differentiation were excluded. World Health Organization classification of exocrine pancreatic tumors assigns spindle cell carcinoma, sarcomatoid carcinoma and carcinosarcoma under the category of undifferentiated (anaplastic) carcinoma [11,12], since the majority of these types of tumor harbors a spindle element that demonstrates an epithelial immunohistochemical profile and/or genetic alterations in pancreatic ductal adenocarcinomas $[1,13]$.

In addition to the tumor of the present case study, nine additional examples of pancreatic sarcomatoid carcinoma with confirmed epithelial derivation of the spindle component and/or absence of specific mesenchymal differentiation have been identified in a comprehensive review of literature. Of the previously reported nine cases (Table 1), only two patients had metastatic disease at presentation

Correspondence to: Rakul Nambiar K, Division of Medical Oncology, Regional Cancer Centre, Trivandrum, Kerala, India, E-mail: rakulnambiar@yahoo.com

Key words: sarcomatoid carcinoma, pancreas, metastases

Received: April 06, 2017; Accepted: May 09, 2017; Published: May 11, 2017 
Table 1. Summary of reported cases of sarcomatoid carcinoma of pancreas

\begin{tabular}{|c|c|c|c|c|c|c|c|c|}
\hline $\begin{array}{c}\text { Age } \\
\text { (years) }\end{array}$ & Gender & $\begin{array}{c}\text { Tumor size } \\
(\mathrm{cm})\end{array}$ & Pancreas & Extent & Sarcomatoid component & Treament & Follow-up, months/outcome & Reference \\
\hline 74 & Male & $\begin{array}{l}4.5 \times 4.0 \\
\quad \times 3.0\end{array}$ & Head & $\begin{array}{l}\text { Duodenal invasion, } \\
\text { with blood vessel } \\
\text { and perineural }\end{array}$ & $\begin{array}{l}\text { CK AE1, variable CK AE3, } \\
\text { EMA, MUC1-ARA (D+), } \\
\text { S100, SMA (F+), desmin, } \\
\text { vimentin, NSE and CEA (-) }\end{array}$ & Pancreatodudenectomy & $\begin{array}{l}\text { 3/succumbed to diffuse peritoneal } \\
\text { carcinomatosis }\end{array}$ & {$[2]$} \\
\hline 74 & Male & $4.0 \times 3.0$ & Head & $\begin{array}{l}\text { Peripancreatic } \\
\text { adipose tissue and } \\
\text { the duodenal wall. }\end{array}$ & $\begin{array}{c}\text { vimentin }(\mathrm{D}+), \mathrm{CK}(\mathrm{F}+), \\
\text { CEA, SMA, desmin and } \\
\text { CD68 (-) }\end{array}$ & pancreaticoduodenectomy & 4/alive and well & {$[3]$} \\
\hline 67 & Female & $\begin{array}{l}2.5 \times 2.5 \\
\quad \times 2.0\end{array}$ & Head & $\begin{array}{c}\text { Peripacreatic } \\
\text { lymphadenopathy }\end{array}$ & $\begin{array}{l}\mathrm{SC} \text {, separate focus of OGC; } \\
\mathrm{IHC}(\mathrm{SC}): \mathrm{CK} 8 / 18 \text { and } \\
\text { vimentin }(\mathrm{D}+)\end{array}$ & pancreaticoduodenectomy & 8/NA & {$[4]$} \\
\hline 72 & Female & NA & NA & NA & $\mathrm{CK}$ and vimentin $(\mathrm{F}+)$ & Conservative & $\begin{array}{l}9 / \text { succumbed to sarcomatoid } \\
\text { carcinoma metastatic to the liver }\end{array}$ & {$[5]$} \\
\hline 82 & Female & $18 \times 11 \times 10$ & Head & $\begin{array}{l}\text { penetrated } \\
\text { the transverse } \\
\text { mesocolon, } \\
\text { resulting in massive } \\
\text { hemorrhagic } \\
\text { clots in the } \\
\text { abdominal cavity. }\end{array}$ & $\begin{array}{c}\text { SC, foci of OGC around } \\
\text { hemorrhage; IHC (SC): } \\
\text { vimentin, CD10 (D+), CK } \\
\text { AE1/AE3 (F+), CK7, CK20, } \\
\text { CEA, EMA, SMA and } \\
\text { S100(-) }\end{array}$ & $\begin{array}{c}\text { Radical } \\
\text { pancreatoduodenectomy } \\
\text { with partial resection of } \\
\text { the transverse colon }\end{array}$ & $\begin{array}{l}\text { 0/Succumbed to DIC on post- } \\
\text { operative day } 13\end{array}$ & {$[6]$} \\
\hline 48 & Male & $\begin{array}{l}3.5 \times 2.5 \\
\times 1.5\end{array}$ & Body & Liver mets & $\begin{array}{c}\text { SC, scattered OGC; IHC } \\
\text { (SC): vimentin (D+), pan-CK, } \\
\text { CK, 7, CK8/18, EMA, CEA, } \\
\text { CD34, CD56, CD68, CD117, } \\
\text { desmin, SMA, myogenin, } \\
\text { S100, ER and PR (-) }\end{array}$ & $\begin{array}{l}\text { Pancreatectomy with } \\
\text { splenectomy and colonic } \\
\text { segmental resection }\end{array}$ & $\begin{array}{l}4 / \text { succumbed to hepatic and } \\
\text { peritoneal metastases }\end{array}$ & [7] \\
\hline 85 & Male & $\begin{array}{l}3.3 \times 3.0 \\
\times 2.6\end{array}$ & Body & $\begin{array}{l}\text { adherent to the } \\
\text { serosa of the } \\
\text { stomach }\end{array}$ & $\begin{array}{c}\text { diffuse pan-CK, CK5.2, } \\
\text { p53 (D+), synaptophysin, } \\
\text { chromogranin, calponin, } \\
\text { S100, SMA, CK19, MUC1, } \\
\text { nuclear ß-Catenin, p63, EMA } \\
\text { and CD10 (-) }\end{array}$ & $\begin{array}{c}\text { Distal (near-total) } \\
\text { pancreatectomy, } \\
\text { splenectomy and partial } \\
\text { gastrectomy }\end{array}$ & 26/alive and well & {$[8]$} \\
\hline 48 & Male & $10 \times 8 \times 5$ & Tail & Nil & CK 18 and vimentin & $\begin{array}{l}\text { Left pancreatectomy, } \\
\text { adjuvant gemcitabine } 1 \\
\text { cycle }\end{array}$ & $3 /$ succumbed & [9] \\
\hline 55 & Male & $14 \mathrm{~cm}$ & Body and tail & NA & $\mathrm{CK}, \mathrm{CK} 7$ and vimentin & \begin{tabular}{|} 
Distal pancreatectomy, \\
splenectomy and colonic \\
segmental resection
\end{tabular} & NA & {$[10]$} \\
\hline 41 & Male & $2.2 \times 2.1 \mathrm{~cm}$ & $\begin{array}{l}\text { Head and } \\
\text { uncinate }\end{array}$ & Liver mets & $\mathrm{CK}$ and vimentin & Gemcitabine & 1, On chemotherapy & \\
\hline
\end{tabular}

CK:Cytokeratin; IHC:Immunohistochemistry; SC:Spindle Cell; EMA:Epithelial Membrane Antigen; SMA:Smooth Muscle Actin; MUC1-ARA:Apoprotein MUC1; (D+):Diffusely Positive; ER:Estrogen Receptor; PR:Progesterone Receptor; OGC:Osteoclastic Giant Cells; DIC:Disseminated Intravascular Coagulopathy; NA:Not Available; NSE:Neuron-Specific Enolase; CEA:Carcinoembryonic Antigen

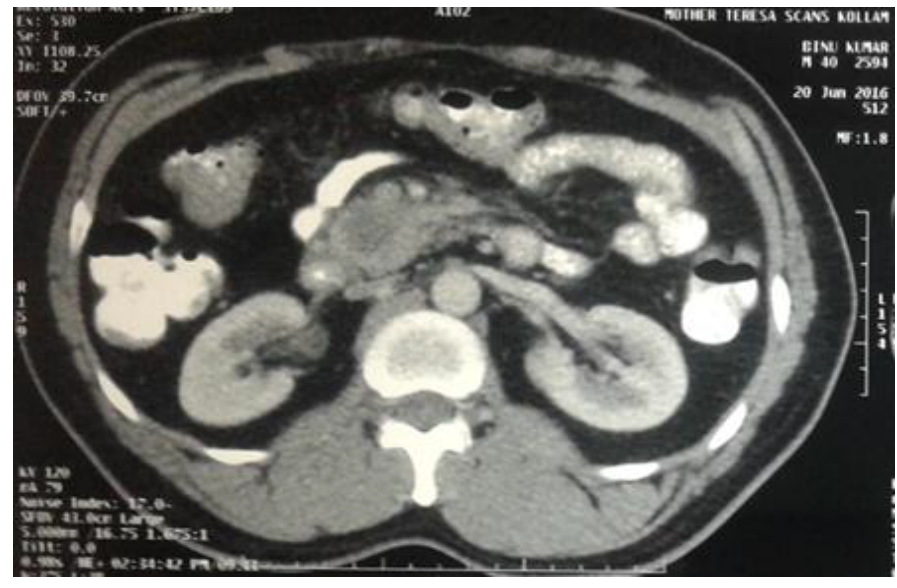

Figure 1. CT abdomen (Axial view) showing ill-defined hypodense lesion in the uncinate process of pancreas

similar to our case and both patients had liver metastasis. Of the patients with adequate follow-up, six out of seven patients succumbed to their condition within nine months of surgery. Longest survival was twenty-six months, documented in a 85 year old male who

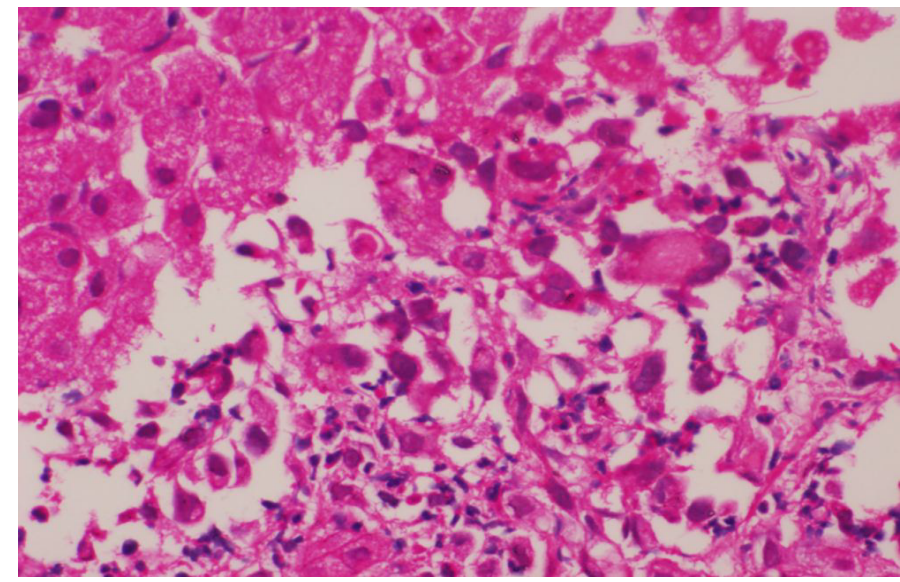

Figure 2. H\& E stain (20X) showed spindle cells with abundant eosinophilic cytoplasm and pleomorphic nuclei admixed with inflammatory cells

underwent distal (near-total) pancreatectomy, splenectomy and partial gastrectomy [8]. In a previous review of pancreatic tumors classified as 'carcinosarcomas', including two cases that are included in the present case report as examples of sarcomatoid (spindle cell) carcinoma [3,4], 


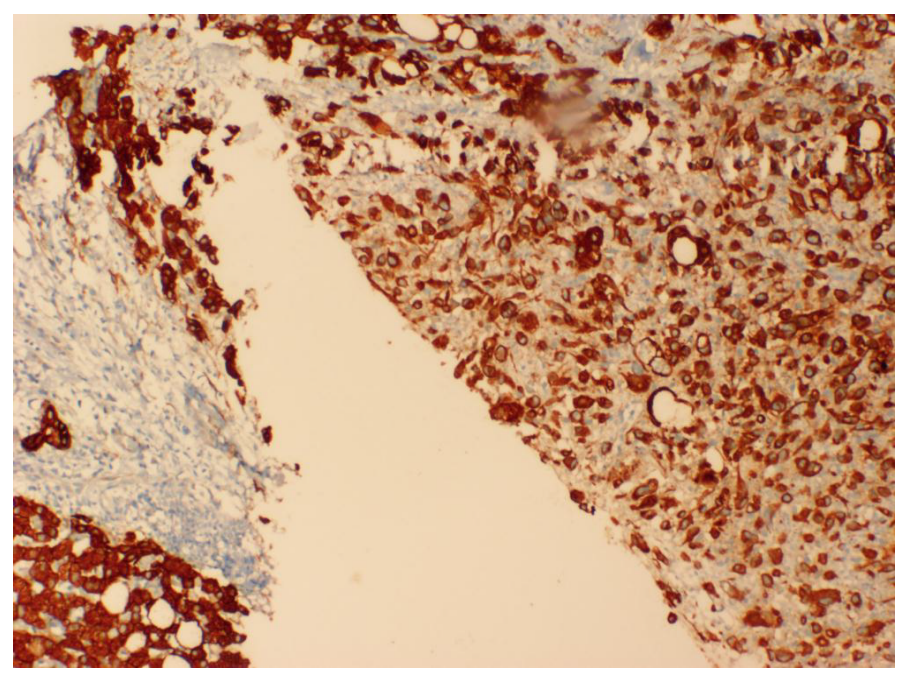

Figure 3. Immunohistochemical staining showed strong positivity for cytokeratin

average post-operative survival interval was six months and that the longest living patient survived for fifteen months. In conclusion, the current case study documents the tenth case of sarcomatoid (spindle cell) carcinoma of the pancreas with data substantiating the epithelial derivation of the nondescript malignant spindle cell element.

\section{References}

1. Balercia G, Bhan AK, Dickersin GR (1995) Sarcomatoid carcinoma: an ultrastructural study with light microscopic and immunohistochemical correlation of 10 cases from various anatomic sites. Ultrastruct Pathol 19: 249-263. [Crossref]

2. Higashi M, Takao S, Sato E (1999) Sarcomatoid carcinoma of the pancreas: a case report with immunohistochemical study. Pathol Int 49: 453-456. [Crossref]
3. Darvishian F, Sullivan J, Teichberg S, Basham K (2002) Carcinosarcoma of the pancreas: a case report and review of the literature. Arch Pathol Lab Med 126: 11141117. [Crossref]

4. Barkatullah SA, Deziel DJ, Jakate SM, Kluskens L, Komanduri S (2005) Pancreatic carcinosarcoma with unique triphasic histological pattern. Pancreas 31: 291-292. [Crossref]

5. De la Riva S, Muñoz-Navas MA, Betés M, Súbtil JC, Carretero C, et al. (2006) Sarcomatoid carcinoma of the pancreas and congenital choledochal cyst. Gastrointest Endosc 64: 1005-1006. [Crossref]

6. Nakano T, Sonobe H, Usui T, Yamanaka K, Ishizuka T, et al. (2008) Immunohistochemistry and K-ras sequence of pancreatic carcinosarcoma. Pathol Int 58: 672-677. [Crossref]

7. Kim HS, Joo SH, Yang DM, Lee SH, Choi SH, et al. (2011) Carcinosarcoma of the pancreas: a unique case with emphasis on metaplastic transformation and the presence of undifferentiated pleomorphic high-grade sarcoma. J Gastrointestin Liver Dis 20: 197-200. [Crossref]

8. Kane JR, Laskin WB, Matkowskyj KA, Villa C, Yeldandi AV (2014) Sarcomatoid (spindle cell) carcinoma of the pancreas: A case report and review of the literature. Oncol Lett 7: 245-249. [Crossref]

9. Yao J, Qian JJ, Zhu CR, Bai DS, Miao Y (2013) Laparoscopic left pancreatectomy for pancreatic sarcomatoid carcinoma: A case report and review of the literature. Oncol Lett 6: 568-570. [Crossref]

10. Lai CW, Chen CW, Lee YH, Chen JH (2015) Sarcomatoid carcinoma of the pancreas. Tzu Chi Medical Journal 27: 46-47.

11. Basturk O, Hong SM, Wood LD, Adsay NV, Albores-Saavedra J, et al. (2015) A Revised Classification System and Recommendations from the Baltimore Consensus Meeting for Neoplastic Precursor Lesions in the Pancreas. Am J Surg Pathol 39: 17301741. [Crossref]

12. Bosman FT, Carneiro F, Hruban RH, Theise ND, editors (2010) World Health Organization Classification of Tumours of the Digestive System. (edn. 4) IARC Press; Lyon, France $p p$. 292-295.

13. Kane JR, Laskin WB, Matkowskyj KA, Villa C, Yeldandi AV (2014) Sarcomatoid (spindle cell) carcinoma of the pancreas: A case report and review of the literature. Oncol Lett 7: 245-249. [Crossref]

Copyright: (2017 Nambiar RK. This is an open-access article distributed under the terms of the Creative Commons Attribution License, which permits unrestricted use, distribution, and reproduction in any medium, provided the original author and source are credited. 